\title{
Implication of an Intramammary Sentinel Lymph Node in Breast Cancer: Is This a True Sentinel Node? A Case Report
}

\author{
Takaaki Fujii Reina Yajima Asuka Matsumoto Sayaka Yamaki Nobuyuki Uchida \\ Soichi Tsutsumi Takayuki Asao Hiroyuki Kuwano
}

Department of General Surgical Science, Graduate School of Medicine, Gunma University, Japan

\section{Key Words \\ Breast cancer $\cdot$ Intramammary node $\cdot$ Sentinel node}

\section{Summary}

Background: Intramammary lymph nodes (ILN) are often diagnosed by final histological examination. Recently, sentinel lymph node biopsy (SLNB) has been developed as a new standard in the treatment of breast cancer. However, reports describing intramammary sentinel nodes (ISLNs) are relatively rare, and the clinical significance of metastases in ISLNs is still unclear. Case Report: We herein report a patient with breast cancer with an ISLN that was detected prior to surgery. In the current case, the ISLN contained foci of carcinoma, but the axillary SLNs (aSLN) did not contain such foci. Previous reports related to ISLNs and aSLNs, including our case, are reviewed. Interestingly, there was no case with negative ISLNs and positive aSLNs. Conclusions: The current and previous cases have shown that axillary lymph node dissection (ALDN) might rely on the aSLN status but not on the ISLN status. The effect on the prognosis or clinical significance in cases with positive ISLNs has not been fully elucidated. Cases of ISLNs found by SLN navigation are discussed in relation to their clinical significance.

\author{
Schlüsselwörter \\ Brustkrebs - Mammalymphknoten, interner . \\ Sentinel-Lymphknoten
}

\section{Zusammenfassung}

Hintergrund: Interne Mammalymphknoten (ILN) werden oft aufgrund der abschließenden histologischen Analyse diagnostiziert. Vor kurzem ist die Sentinel-LymphknotenBiopsie (SLNB) als neuer Standard bei der Behandlung von Brustkrebs entwickelt worden. Berichte über Sentinel-Lymphknoten innerhalb der Brust (ISLNs) sind relativ selten und die klinische Bedeutung von Metastasen in ISLNs ist noch unklar. Fallbericht: Wir berichten hier über eine Brustkrebspatientin mit einem ISLN, der vor der Operation entdeckt worden war. Im vorliegenden Fall enthielt der ISLN einige Karzinomherde, während in den axillären Sentinel-Lymphknoten (aSLNs) keine zu finden waren. Frühere Berichte über ISLNs und aSLNs einschließlich unseres Falles werden im Überblick dargestellt. Interessanterweise gab es keinen Fall mit negativen ISLNs und positiven aSLNs. Schlussfolgerungen: Der vorliegende Fall und die früheren Fälle zeigen, dass sich die Entscheidung über eine Entfernung der axillären Lymphknoten (ALDN) auf den Status der aSLNs, aber nicht auf den der ISLNs stützen könnte. Der Effekt für die Prognose oder die klinische Bedeutung in Fällen mit positiven ISLNs ist noch nicht vollständig geklärt. Fälle von ISLNs, die durch die direkte Suche nach SLNs gefunden wurden, werden in Bezug auf ihre klinische Bedeutung diskutiert.

\begin{tabular}{ll}
\hline KARGER & @ 2010 S. Karger GmbH, Freiburg \\
Fax +497614520714 & Accessible online at: \\
Information@Karger.de & www.karger.com/brc \\
www.karger.com &
\end{tabular}




\section{Introduction}

The status of the axillary lymph nodes is the most significant prognostic factor for patients with breast cancer. Sentinel lymph node biopsy (SLNB) has been developed as a new standard in the treatment of breast cancer. This technique represents a minimally invasive operative procedure, a highly accurate method of axillary staging, and an alternative to conventional axillary lymph node dissection (ALND) [15]. The technique of SLN detection must be improved to avoid false negatives, and a few case reports have described the successful detection of intramammary SLNs (ISLNs) [611]. Intramammary lymph nodes (ILNs) are detected in $1-28 \%$ of breasts [12-14]. However, the clinical significance of metastasis in ILNs is unclear, especially in cases of ISLNs undergoing an SLN navigation surgery [6-11, 14-19]. We herein report the case of a breast cancer patient with an ISLN that was detected prior to surgery. In this case, the ISLN was positive and was the only site of metastatic disease. The clinical significance of the detection of ISLNs is discussed in this report.

\section{Case Report}

A 70-year-old Japanese woman was found to have a $1.5-\mathrm{cm}$ palpable tumor in the right upper external breast quadrant and clinically negative axillary nodes. The core needle biopsy revealed the presence of an invasive ductal carcinoma with associated ductal carcinoma in situ. SLNB was performed using both a radioisotope tracer and blue dye injection. Briefly, $12 \mathrm{~h}$ prior to surgery, the radioisotope with $99 \mathrm{mTc}$-phytate colloid was injected subcutaneously into the periareolar region. Intradermal injection of a blue dye, indigocarmine, in the periareolar region was also performed immediately prior to surgery. Any lymph nodes with blue dye and radioactivity were regarded as SLN. The ILN was detected by preoperative magnetic resonance imaging (MRI) but not by preoperative mammograms. Lymphoscintigraphy revealed an ISLN. Breast-conserving surgery was performed. At operation, two axillary SLNs (aSLNs) were detected with blue dye and without hot (radioactive) tracer. Intraoperative diagnosis of the aSLNs was negative for metastasis, thus avoiding additional conventional ALND. At final histology, none of the aSLNs was metastatic. A metastatic ISLN was found on pathological examination of the surgical specimen. The patient received adjuvant hormone therapy and radiotherapy. The patient has been alive for 11 months without locoregional or systemic recurrence of the tumor.

\section{Discussion}

SLNB has been developed as a minimally invasive operative procedure to precisely determine the presence of axillary lymph node metastases in patients with clinically negative nodes [1-5]. ILNs themselves are not rare and are detected in $1-28 \%$ of breasts [12-15]. However, ILNs are often diagnosed by final histological examination, and only several case series have described ISLNs [6-11]. Because of their relatively rare presentation, the clinical significance of ISLNs remains un- clear. We here report a case of a metastatic ISLN in breast cancer. The key observations of our case are summarized as follows: (i) Preoperative lymphoscintigraphy revealed an ISLN and (ii) the ISLN had foci of metastasis and the aSLNs were free of disease.

According to several reports and depending on the detection method used, ILNs can be rarely or frequently detected; ILNs are detected in 1-28\% of breasts [12-14]. ILN may also correspond to early node involvement of breast cancer [14]. Shen et al. and others have demonstrated that metastatic ILNs were an independent factor for specific and global decrease in survival [14-17]. Similarly, Guth et al. reported that patients with positive ILNs had more aggressive cancers, including higher rates of lymphovascular invasion and axillary lymph node metastasis [16]. In contrast, patients with positive ILNs had improved prognosis over those patients with a positive aSLN [18]. However, these are reports regarding ILN in which surgical specimens were retrospectively studied, but not ISLN obtained by SLNB. Whether the detection of an ISLN affects the prognosis remains difficult to assess due to their low reported incidence. The benefit of systemic adjuvant therapy in the presence of a positive ISLN is also difficult to assess; nevertheless, such a therapy may need to be considered.

With the use of SLNB, one would expect to detect ISLN using preoperative lymphoscintigraphy. The feasibility of noninvasive imaging modalities for SLN mapping has indicated a good potential for fine-needle aspiration or microbiopsy in the subsequent investigation of ISLNs identified noninvasively. However, whether the detection of ISLN metastasis affects aSLNs or axillary non-SLNs also remains difficult to assess due to the low reported incidence of ISLN metastasis. There is no consensus on how to interpret the information provided by an ISLN biopsy to inform surgical decisions. A few reports have shown distinct clinical data related to ISLNs. In our case, both an ISLN and aSLNs were identified, and the ISLN had foci of metastasis while the aSLNs were free of disease. Previous reports related to ISLNs and aSLNs, including our case, are reviewed in table 1. 25 cases had ISLNs; all cases were identified as showing both ISLNs and aSLNs. In 11 cases, both the ISLNs and aSLNs were negative. In 12 cases, the ISLNs were positive and the aSLNs were negative. In 2 cases, both the ISLNs and aSLNs were positive. Interestingly, there was no case with negative ISLNs and positive aSLNs. There are two possible explanations for this result: (i) ISLNs are 'true' sentinel nodes of aSLNs and (ii) the ectopic lymphatic pathway to ISLNs develops individually. Vijan et al. reported that patients with positive ILNs have a high incidence of axillary disease [19], and the possibility that ISLNs are sentinel nodes of aSLNs cannot be discounted completely. However, some reports have revealed that ISLNs were found in areas apart from those within the tumor and the axilla [6, 7]; this situation is considered to occur by means of the ectopic lym- 
Table 1. Reports of cases with an intramammary sentinel lymph node

\begin{tabular}{|c|c|c|c|c|}
\hline \multirow[b]{2}{*}{ Reference } & \multirow[b]{2}{*}{$\begin{array}{l}\text { Number of patients } \\
\text { with ISLNs }\end{array}$} & \multicolumn{3}{|c|}{ Number of patients with } \\
\hline & & $\begin{array}{l}\text { negative ISLN } \\
\text { negative aSLN }\end{array}$ & $\begin{array}{l}\text { positive ISLN } \\
\text { negative aSLN }\end{array}$ & $\begin{array}{l}\text { positive ISLN } \\
\text { positive aSLN }\end{array}$ \\
\hline Intra et al., 2009 [6] & 15 & 9 & 6 & \\
\hline Kijima et al., 2008 [7] & 4 & 2 & 2 & \\
\hline Mathelin et al., 2005 [8] & 2 & 1 & 1 & \\
\hline Tytle et al., 2003 [9] & 1 & & & 1 \\
\hline Gajdos et al., 2001 [10] & 1 & & & 1 \\
\hline Rull et al., 1999 [11] & 1 & & 1 & \\
\hline Present case, 2010 & 1 & & 1 & \\
\hline Total & 25 & 12 & 11 & 2 \\
\hline
\end{tabular}

ISLN = Intramammary sentinel lymph node; aSLN = axillary sentinel lymph node. phatic pathway. Therefore, anyway, if the ISLN is positive and the aSLN is negative, we consider that complete ALND could be avoided. In other words, the management of the axilla should rely on the aSLN status, as previously discussed $[6,9,18]$.

In conclusion, we herein report a case of breast cancer with an ISLN that was detected prior to surgery. The current and previous cases have shown that ALDN might rely on the aSLN status but not on the ISLN status. The effect on the prognosis or clinical significance in cases with positive ISLN has not been fully elucidated due to the small number of such cases, and further analyses of a large number of cases are warranted to evaluate the clinical significance.

\section{Conflict of Interest}

The authors declare that they have no competing financial interests.

\section{References}

1 Giuliano AE, Kirgan DM, Guenther JM, Morton DL: Lymphatic mapping and sentinel lym phadenectomy for breast cancer. Ann Surg 1994; 220:391-401.

2 Albertini JJ, Lyman GH, Cox C, Yeatman T, Balducci L, Ku N, Shivers S, Berman C, Wells K, Rapaport D, Shons A, Horton J, Greenberg H, Nicosia S, Clark R, Cantor A, Reintgen DS: Lymphatic mapping and sentinel node biopsy in the patient with breast cancer. JAMA 1996;276:1818-1822.

3 Krag D, Weaver D, Ashikaga T, Moffat F, Klimberg VS, Shriver C, Feldman S, Kusminsky R, Gadd M, Kuhn J, Harlow S, Beitsch P: The sentinel node in breast cancer. A multicenter validation study. N Engl J Med 1998;339:941-946.

4 Veronesi U, Paganelli GT, Galimberti V, Viale G, Zurrida S, Bedoni M, Costa A, de Cicco C, Geraghty JG, Luini A, Sacchini V, Veronesi P: Sentinel-node biopsy to avoid axillary dissection in breast cancer with clinically negative lymph-nodes. Lancet 1997;349:1864-1867.

5 Kuehn T, Bembenek A, Decker T, Munz DL, Sautter-Bihl ML, Untch M, Wallwiener D: Consensus Committee of the German Society of Senology. Cancer 2005;103:451-461.

6 Intra M, Garcia-Etienne CA, Renne G, Trifro G, Rotmensz N, Gentillini OD, Galimberti V, Sagona A, Mattar D, Sangalli C, Gatti G, Luini A, Veronesi U: When sentinel lymph node is intramammary. Ann Surg Oncol 2008;15:1304-1308.
Kijima Y, Yohinaka H, Uenosono Y, Funasako Y Ehi K, Yanagita S, Arima H, Kozono T, Arigami T, Natsugoe S, Aikou T: Intramammary sentinel lymph node in patients with breast cancer: Report of four cases. Surg Today 2008;38:536-540.

8 Mathelin C, Tomasetto C, Rio MC, Chenard MP, Brettes JP, Guyonnet JL: Improvement in intramammary sentinel lymph node removal using a novel prototype hand held probe during breast conservative surgery. Breast Cancer Res Treat 2005;89:305-308.

9 Tytle I, Hayes A, Kissin M: Intramammary sentinel lymph nodes in early breast cancer: can we find them and do they matter? Eur J Surg Oncol 2003:29:6-8.

10 Gajdos C, Bleiweiss IJ, Drossman S, Tartter PI: Breast cancer in an intramammary sentinel node. Breast J 2001;7:260-262.

11 Rull M, Fraile M, Alastrué A, Castellà E, Calatrava A, Riba J, Julián JF, Barnadas A: Histologically invaded intramammary sentinel node, but no metastases found on axillary dissection. Eur J Surg 1999;165:1100-1102.

12 Egan RL, McSweeney MB: Intramammary lymph nodes. Cancer 1983;51:1838-1842.

13 Jadusingh IH: Intramammary lymph nodes. J Clin Pathol 1992;45:1023-1026.
14 Shen J, Hunt KK, Mirza NQ, Krishnamurthy S, Singletary SE, Kuerer HM, Meric-Bernstam F, Feig B, Ross MI, Ames FC, Babiera GV: Intramammary lymph node metastases are an independent predictor of poor outcome in patients with breast cancer. Cancer 2004;101:1330-1337.

15 Upponi S, Kalra S, Poultsidis A, Bobrow L, Purushotham AD: The significance of intramammary nodes in primary breast cancer. Eur J Surg Oncol 2001;27:707-708.

16 Guth AA, Mercado C, Roses DF, Hiotis K, Skinner K, Diflo T: Intramammary lymph nodes and breast cancer: a marker for disease severity, or just another lymph node? Am J Surg 2006;192:502-505.

17 Hogan BV, Peter MB, Shenoy H, Horgan K, Shaaban A: Intramammary lymph node metastasis predicts poorer survival in breast cancer patients. Surg Oncol 2010;19:11-16.

18 Cox CE, Cox JM, Ramos D, Meade TL: Intramammary sentinel lymph nodes: what is the clinical significance? Ann Surg Oncol 2008;15:1273-1274.

19 Vijan SS, Hamilton S, Chen B, Reynolds C, Boughey JC, Degnim AC: Intramammary lymph nodes: Patterns of discovery and clinical significance. Surgery 2009;145:495-499. 